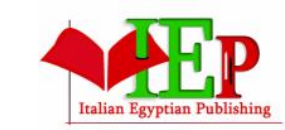

ISSN: $2735-4415$
INTERNATIONAL JOURNAL OF

MULTIDISCIPLINARY STUDIES IN ARCHITECTURE

AND CULTURAL HERITAGE

VOLUME 3, ISSUE 1, 2020, 82-98.

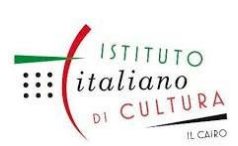

www.egyptfuture.org/ojs/

\title{
History OF Bell-Towers in Ancient Coptic Churches
}

Maha Aboubakr Ibrahim a, *

a Department of Architecture, Faculty of Engineering, Misr University for Science and Technology, Egypt

\begin{abstract}
The bell-tower is a well-known architectural element in any church. It makes from the church a landmark for the surrounding area. However, all of the documented architectural plans of the ancient Coptic churches have no place for the bell tower. This is according to the documentations of important authors and researchers in this field, such as; Somers Clark, Alfred Butler and Peter Grossmann and others. Therefore, the main interest of this paper is to determine the date in which Copts began to build up their bell-towers in churches, even if approximately. That by observing the documented plans, historical texts or even arts, to deduce the earliest bell-towers in Coptic churches. Therefore, we can mention the date Copts needed to build them or even were able to. This methodology gives the opportunity, moreover, to determine the regional influences (from the nearby middle east, Mediterranean, African....etc.) that reflected on the Coptic bell-towers from the early beginning, and even the local influences. Furthermore, this research traces the evolution of the Coptic bell-towers and, accordingly, their structural development. Also, their location on the church plan and their relation with other components of the church.

This study can be considered as a piece that accumulates a scientific architectural figure about the ancient Coptic churches that survives since the fourth century, and represents a part of the Mediterranean heritage. Consequently, contemporary architects of churches, can revive this heritage and add their evolutions to it according to the contemporary social and religious needs, and developed technology.

Keywords

- $\quad$ Coptic Churches.

- Bell-Tower.

- $\quad$ Multicultural.

- $\quad$ Mediterranean Heritage.
\end{abstract}

\section{Introduction}

By tracing the plans of Coptic ancient churches, from the fourth to ninth centuries, there is no evidence about the existence ofthe bell towers. This paper concerns about tracing the history of bell towers in Coptic churches that time. There is no exact time when Copts began building and constructing bell towers in their churches. Accordingly, we can introduce its location in the church, form and height.

Such analysis, helps to deduce if Copts were influenced by other cultures or not, or if there were a cross-cultural exchange? and if they did, which cultures are the most influential for them?

\section{Historical Background about Coptic Bell- Towers:}

There are no clear or precise information about the history of bell-towers in Coptic churches. Authors had different estimates about its history and origins. Yet, to build up an overview, the researcher of this paper tried hardly to collect pieces of information about this issue from here and there.

By reviewing what has been written by scholars and researchers in this regard, we can find that; the monk Pastor AthanasiusMakar (Makar, 2008) mentioned that bell- 


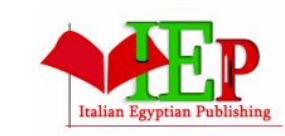

ISSN: $2735-4415$
INTERNATIONAL JOURNAL OF

MULTIDISCIPLINARY STUDIES IN ARCHITECTURE

AND CULTURAL HERITAGE

VOLUME 3, ISSUE 1, 2020, 82-98.

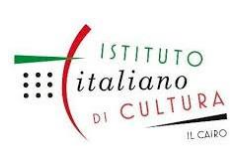

www.egyptfuture.org/ojs/

towers were not known in the east beforemiddle ages, i.e. between 5 th and 15 th centuries. He referred his information to A. Butler (Butler, 1970) who said that in Cairo there were any churches with spire or tower, neither the Byzantine campanile nor the Muslim minaret has any counterpart in the ordinary buildings of the Copts. Butler justified that by the Arabic persecution for Christians. Consequently, due to Butler, belfries still exist and in use in the desert monasteries at Wadi El-Natrun and other remote areas, where no Islamic intervention. Moreover, Butler describes the location of the bell-tower with regard to the church as not quite specific, unless it was it was always outside the church building.

Athanasius noted, however, that the Coptic church is considered as one of the oldest churches that used bells, and that Apollinarios the envoy of Justinian (527-565 C.E.) was ringing the bells at the first day of the week at Alexandria, to call people to listen to his speech. He mentioned as well that, in Egypt, by 850 C.E., there was anorder that prevented ringing of bells, and by 1000 C.E. another order was issued to ban the construction of spires. Hence, this means that before 1000 C.E., Copts were allowed to build bell-towers of spires. But since when? So far, there is no documented clue to answer this question.

One of the most important sources to build a perception about the bell-towers generally and especially in Egypt is the ancient frescos, as an important cultural product. Murals in the Church of El-Sourian Monastery of the Holy Virgin Mary in Wadi Natrun are rich and precious. Recent excavations revealed layers of frescos drawn over different periods. The one we care about here is that for Patriarch Demianous (Figure 1). The significance of this fresco is that it dates back to the eighth century (St- takla.org, 2019). Which give a clear signal that Christians in the east world did know church towers before the eleventh century.

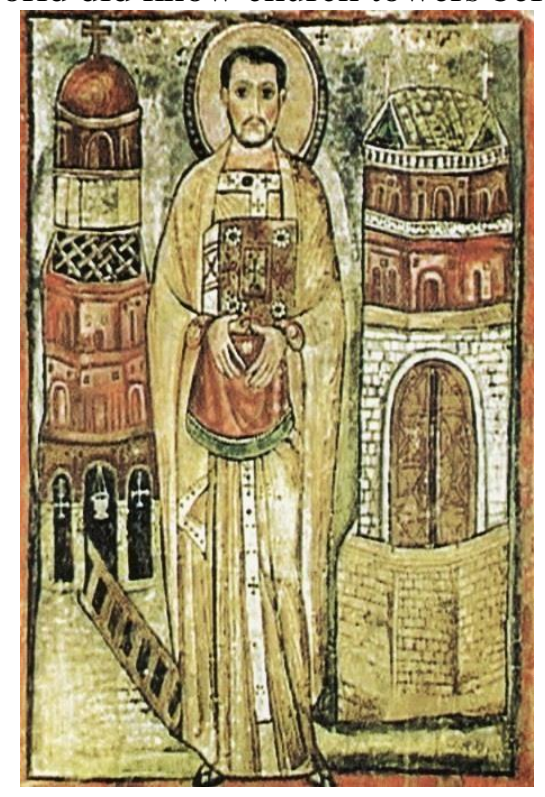




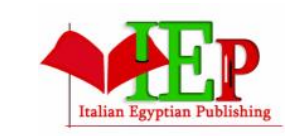

ISSN: $2735-4415$
INTERNATIONAL JOURNAL OF

MULTIDISCIPLINARY STUDIES IN ARCHITECTURE

AND CULTURAL HERITAGE

VOLUME 3, ISSUE 1, 2020, 82-98.

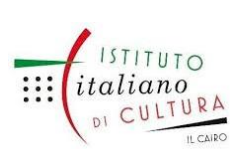

www.egyptfuture.org/ojs/

Figure 1 Fresca for Patriarch Demianous,

on either side of his there are representations of architecture. On the left a tower-like structure thatmay be a church tower, a ladder is standing against it, giving access to the first floor. On the right there is a walled building with a gate.

\section{1- Purposes of Church's Bell-Tower}

There were different uses for the church bell tower. Yousef S. (Yousef, 2006), classified them into; functional purposes and visual ones. However, Makar, A. pointed to its symbolic and spiritual purposes. This partof the research illustrates the church's bell- tower/tower from the three perspectives:

\subsection{Functional Purposes}

The main use of the bell-towers is to call the believers for the prayers at time. In addition of that churches ring its bells to celebrate feasts and also to share sorrows. Also, people hear their sound at the offering the sacrifice as an announcement of the role of Christ on Copts hearts and after the Eucharist rite as well. (Yousef, 2006 and Makar, A. 2008).

\section{Visual Purposes}

Obviously, it is a landmark for the church, as a strong attractive element, because of its vertical proportion in respect of the surrounding context. That causes a sense of contrast in the skyline, which make passengers distinguish the religious building from the others. In addition of its monumental scale, which calls within man a sense of reverence.

\subsection{Origins of the Symbolic Meaning and Purposes of the Bell-Tower}

Originally, the minaret carries the light, that is to say, it is placed at the top of a lamp that guides the walkers in the dark. It is a secret expression of the status of the Church in the world as the center of light and the source of the Spirit of God who guides the oppressors in the darkness of this world (Fekri, A., 2009). This happened in the days of Khedive Abbas I in 1850. When he was returning from his Mediterranean trip to Alexandria on one of the dark winter nights. His ship lost its way and in vain the captain tried to drive to the port. Finally, he glimpsed from afar a dim light, and he beganto follow him until he reached the shore safely. There he began looking for the sourceof this light. To his great delight, he found himself in front of the Church of St. Mark, who at that time oversaw the sea. There wereno buildings booked between them and the sea. He looked in the cabin of St. Mark and discovered the source of light that guided his ship, with a small lantern hanging in front of the icon of the saint, and we talked about this subject here in St. Taklahaimanot in other sections. Vandhash and joy, and recognition of the beauty of the Marquis it officially issued the sum of 271 million (two hundred and seventy-one million) the value of oil consumed annually. (Makar, A., 2008)

Tent of Meeting: on the day that the tent was completed, God showed Himself in the cloud and covered it. Then the cloud was traveling in front of them on their journeys. And if the pillar shall stand above the tent, the people shall come down; In the night the cloud turns into a pillar of fire that is walking before them. And it 


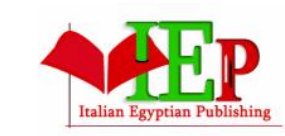

ISSN: $2735-4415$
INTERNATIONAL JOURNAL OF

MULTIDISCIPLINARY STUDIES IN ARCHITECTURE

AND CULTURAL HERITAGE

VOLUME 3, ISSUE 1, 2020, 82-98.

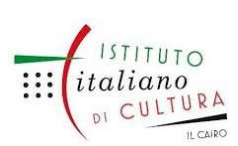

www.egyptfuture.org/ojs/

came to pass, when Pharaoh went on, that the people went into the pillar of cloud between the army of Pharaoh and the cloud, and for Pharaoh and his soldiers was darkness and darkness, and there was fire on the other side of the LORD on the other side. (Makar, A., 2008)

2- Types of Bell-Tower

A bell tower is a tower that contains one or more bells, or that is designed to hold bells even if it has none. Such a tower commonly serves as part of a church, and will contain church bells, but there are also many secular bell towers, often part of a municipal building, an educational establishment, or a tower built specifically to house a carillon. Church bell towers often incorporate clocks, and secular towers usually do, as a public service.

The Italian term campanile, derivingfrom the word campana which means 'bell', is synonymous with bell tower; though inEnglish usage Campanile tends to be used to refer to a free-standing bell tower.

A bell tower may also in some traditions be called a belfry, though this term may alsorefer specifically to the substructure that houses the bells and the ringers rather than the complete tower.

A steeple, in architecture, is a tall toweron a building, topped by a spire and often incorporating a belfry and other components. Steeples are very common on

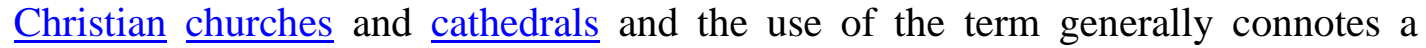
religious structure. They may be stand-alone structures, orincorporated into the entrance or center ofthe building.

A spire is a tapering conical or pyramidal structure on the top of a building, often a skyscraper or a church tower, similar to a steep tented roof. Etymologically, the word is derived from the Old English word spir, meaning a sprout, shoot, or stalk of grass.

A bell-cot, bell-cote or bellcote is a small framework and shelter for one or more bells. Bellcotes are most common in church architecture but are also seen on institutions such as schools. The bellcote may be carried on brackets projecting from a wall or built on the roof of chapels or churches that have no towers. The bellcote often holds the

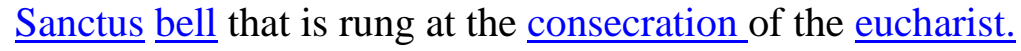

According to A. Almaqari, bell tower is a tower for church bells, suspended at the top by a cross, is often illuminated at night, and the church remains visible during the day as at night. All those who look upon it will healwith faith. [1]

\section{3- History of Bell Towers Abroad}

Information about the origins of constructing bell-towers world wide is more available than that in Egypt. According to Roger J. Smith big bells, for church towers, were not so available until the eleventh century. It is mentioned also that The $\underline{\text { rish }} \underline{\text { round }}$ towers are thought to have functioned in part as bell towers (Figure 2). Though the purpose of such construction is not clear, whether watch towers or religious storage towers, however researchers, such as GeorgePetrie and Dinneen, (Dinneen, 1927). have prevailed that they were bell-towers. As theyassume that they are the origins of churches bell-towers in Europe. Their history goes back to about the 11th century. 


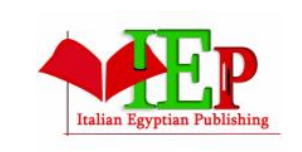

VOLUME 3, ISSUE $1,2020,82-98$.

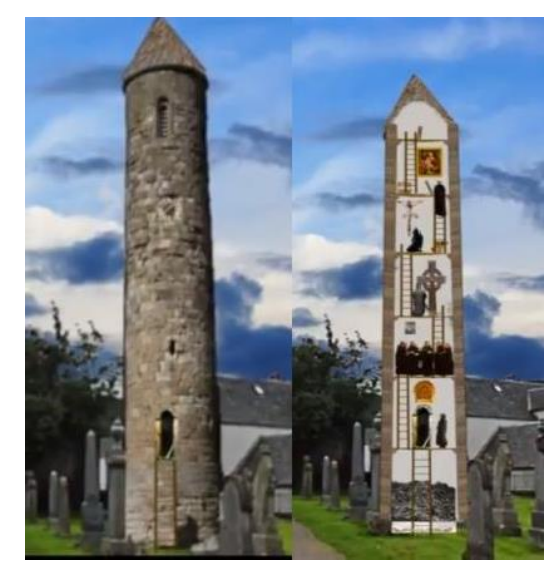

Figure 2 Example of The Irish Round Tower(source: YouTube, 2019)

In china, people were building towers in their ancient temples for civic reasons mainly used for time reporting and publishing news in ancient times. By time similar to that in Europe, Chinese began to build their Christian bell-towers. often pairedwith a drum tower, as well as in local churchbuildings. Among the best known examples is the bell-tower of Xi'an (Figure 3).

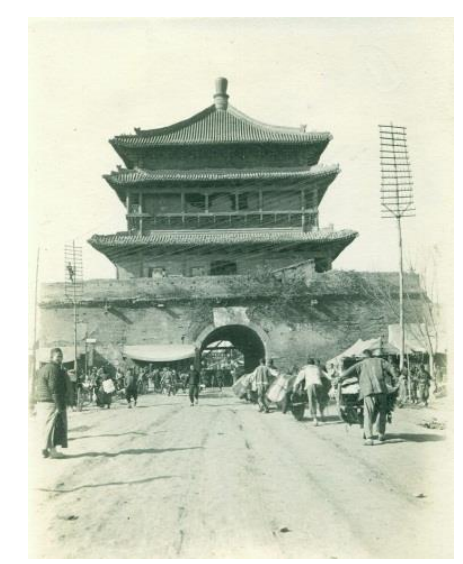

Figure 3 Bell-Tower at Xi'an, China, early 20thcentury.

From another perspective, and by tracing the origins of the Islamic minarets, Creswell (Creswell, 1926) states that the idea of the Islamic minaret first arose under the Umayyad dynasty in Syria, when Muslims saw the Syrian squared church towers (Figure 4, Error! Reference source not found.). It is custom peculiar to Syria that the pre-Muslim typical church tower was squared and of no great height. He proved that by minaret of the Great mosque of Damascus, which was the first Islamic minaret. That mosque was before that theBasilica of St. John or the temple of Jupitar. That was far before the eleventh century bell-towers in Europe or China. In which the Umayyad period dates back to the 7th to the 8th century C.E. 


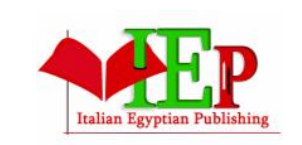

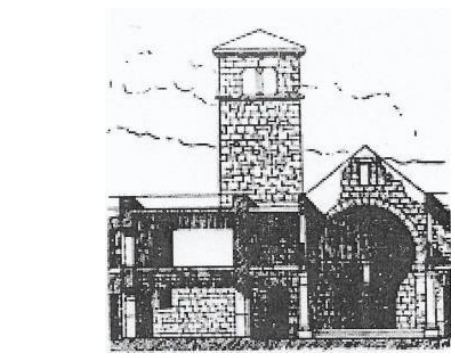

Figure 4

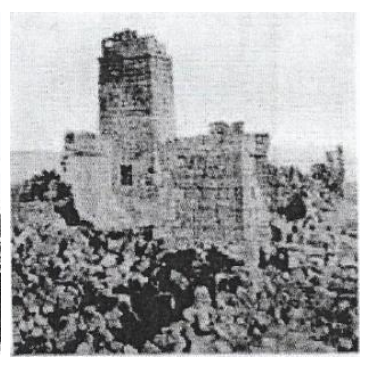

Figure 5

Examples of pre-Islamic typical Syrian squared church towers, confirm that they were exist beforethe 7th century C.E.

Moreover, and keeping up with the idea of having towers in Syria's architecture even before the Early Christianity, it is mentioned that many (pagan) temples of the basilicatype were built in Syria in the first and second century C.E. The tetradic concept of temple building was further pioneered from the middle of the third century $\mathrm{AD}$ onwards. The design with towers at the corners of the roof became a noteworthy feature. The little temple at Djmer (Figure 5 and Figure 5) and also the Great Temple of Bel at Palmyra have staircases at either end of the cella, presumably leading to towers. The Temple of Bel dates from around 32 C.E. and was built during the reign of Tiberius. (Quadralectic Architecture, 2019)

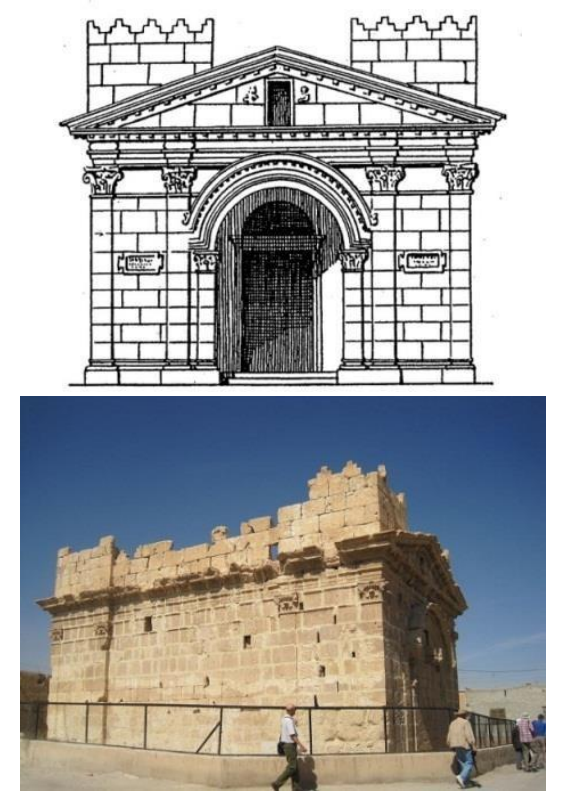

Figure 5 and Figure 6 The temple at Djmer (Syria), consecrated in 245 AD, was dedicated to Zeus. Unlike the Greek temples, it had towers at all four corners of its gabled roof. The temple embodied the idea of a place of worship, a palace precinct, a defensive work and a city-gate in one and became an architectural guideline for times tocome

About the location of the bell-tower in thechurches plan, A. Mondello analysed a large sample od belfries and studied their location according to the churches building 


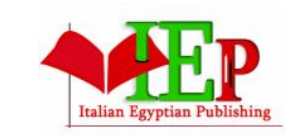

ISSN: $2735-4415$
INTERNATIONAL JOURNAL OF

MULTIDISCIPLINARY STUDIES IN ARCHITECTURE

AND CULTURAL HERITAGE

VOLUME 3, ISSUE 1, 2020, 82-98.

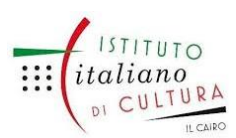

www.egyptfuture.org/ojs/

body, andso he observed that $70 \%$ is made up of bell towers leaning against the church, while the overlapping specimens made up only $20 \%$ and the merged bell towers are just under $10 \%$ as shown in (Figure 7). (Mondello, 2017)

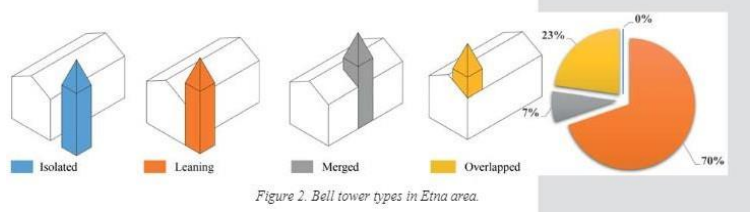

Figure 7 (Mondello, 2017)

It is also worth to mention for the Coptic churches Yousef (Yousef S., 2006) said that there is no specific place for the Coptic bell- tower in the church, however he agrees thatit is usually located near the entrance. While Butler (Butler, 1970) say that they arealways isolated from the body of the church building. And to give a scientific informationabout this issue, this may need field surveys and statistical analyses.

\section{4- History of Bell-Tower in Coptic Churches}

Back to the Coptic bell-towers, this partof the study depends on three sources; a) the description of A. Butler, b) Observations andanalyses of Dr. Samer Samir Yousef (Yousef, 2006), c) the illustrations of the monk Athanasius Makar, and finally d) somewebsites that mentioned the ancient Coptic churches and their bell-towers.

Based on Butler's observation, as he marked that bell-towers still standing and still in use in the desert monasteries and other remote places. That means that bell towers may have been introduced to Coptic churches since a date we don't know exactly.He described those towers as follows:

"These towers are built of brick and covered with plaster: as far as they have any character, they may be called Byzantine. Each tower is usually two stories high, square on plan, and each side in the upper story is relieved by two open arches, highly stilted and round-headed. The position whichthe tower occupies with regard to the church is quite immaterial, but it is always virtually detached" (Butler, 1970)

By describing them as squared in plan, of two storeys high, and the upper storey has rounded arched window and topped by a dome-like shape (Figure 8 ). That brings back to the mind Creswell's description of the Syrian squared towers that mentioned before. And naming them by Byzantine, emphasizes the specificity of the Eastern region in terms of the history of construction and formation. The described form of the church tower by Butler is embodied clearly in the old towers in desert monasteries, such as the Monastery of St. Pishoi at Wadi El-Natrun (Figure 9). That confirms or at least points that churchestowers were existing in Coptic churches since the Early Christian period. This is not contrary to what Butler said about thepresence of bell towers in churches located in the desert and remote areas, but agrees with him and confirms. Moreover, what is worth to mention, is that according to Yousef S. the origin of the idea of towers and minarets is generally does back to theSumerian ziggurats. This is another theory confirms the eastern region speciality in building towers. It refers it to far date older than that of Syrian squared towers and goes back to the ancient periods, where the Mesopotamian civilizations. Furthermore, he mentioned that Rule of Pachomius 
(Westminsterabbey.ca, 2019) mentioned thatmonks have to leave their cells once theyhear the sound of the horns and go for the church, and this habit continued until the time of St. Saint John Climacus, the head of the monasteries of Sinai in the sixth century.

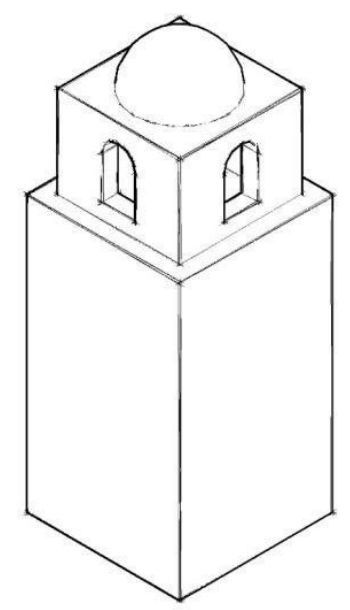

Figure 8 Reconstruction of the Old tower asdescribed by Butler (the researcher)

\section{6-1 Early Towers in Coptic Churches (Between 5th and 6th centuries C.E.)}

According to Yousef S. in his dissertation (Yousef, 2006), that form passed by several stages of evolution. At this point, by usinghis study and by observing the building materials and formulation of the towers, the researcher suggests a chronological order forthe Coptic churches bell towers or just churches towers. Beginning with the supposed to be the oldest, we can trace four of them that occur at: a) St. Pshoi monastery (Figure 9), b) Monastery of St. Paul, Eastern Desert (Figure 10), c) Monastery of St. Antony (Figure 11) and d) the old tower of the forty-Nine Martyrs, the monastery of St.Macarius, Wadi El-Natrun (Figure 12)

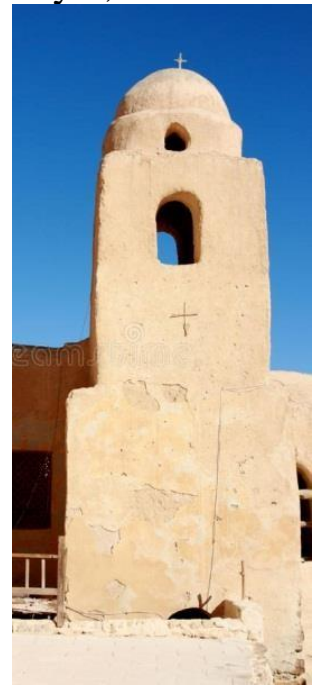

Figure 9 Old tower of St. Pshoi monastery, WadiEl-Natrun 


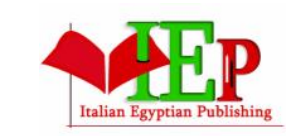

ISSN: $2735-4415$

\section{INTERNATIONAL JOURNAL OF \\ MULTIDISCIPLINARY STUDIES IN ARCHITECTURE \\ AND CULTURAL HERITAGE}

VOLUME 3, ISSUE 1, 2020, 82-98.

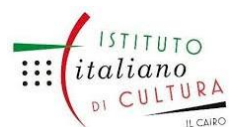

www.egyptfuture.org/ojs/

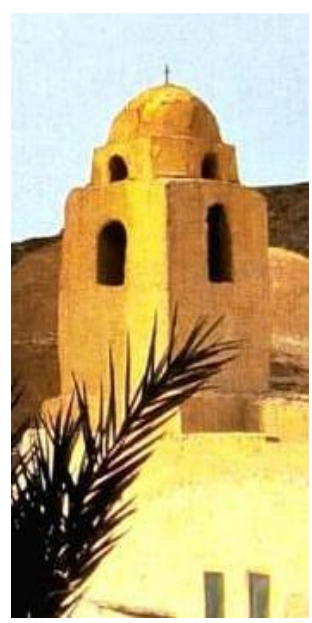

Figure 10 the old tower at the Monastery of St.Paul, Eastern Desert, and Red Sea Coastal.

(Capuani et al., 2002)

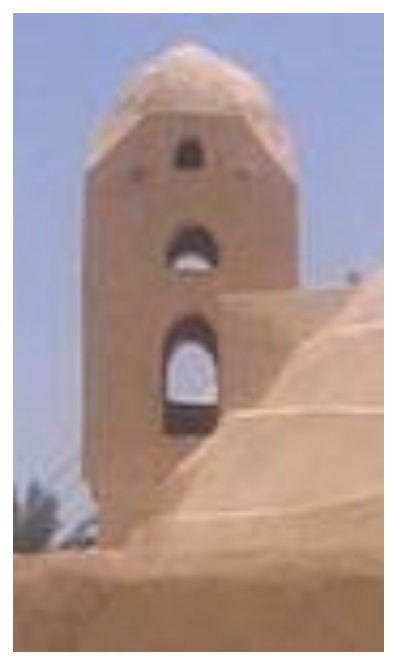

Figure 11 the old tower at the Monastery of St.Antony, Eastern Desert, and Red Sea Coastal (Wikiwand, 2019) 

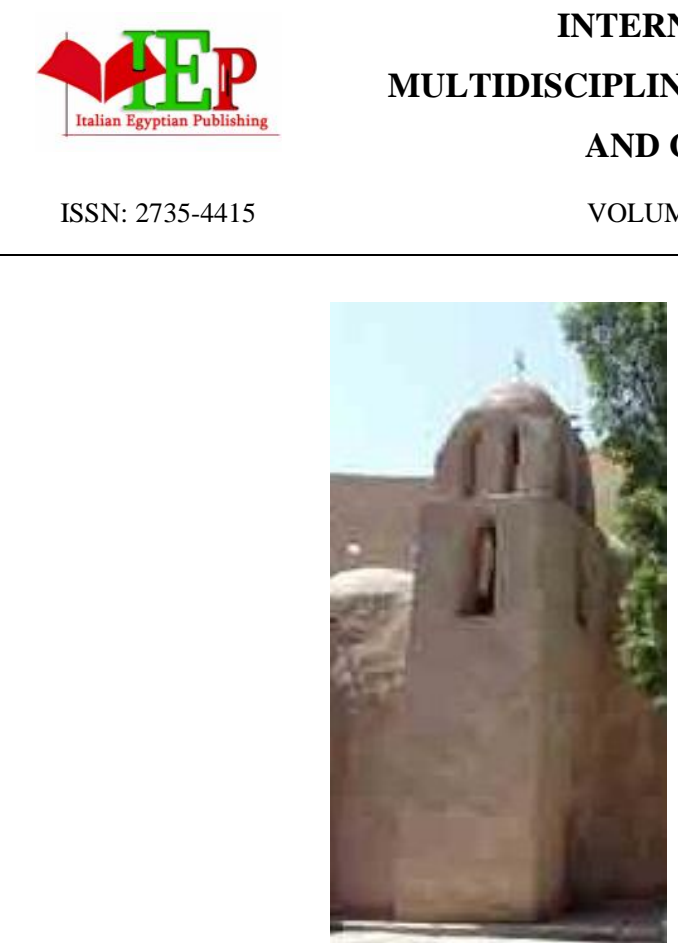

Figure 12 the old tower of the forty-Nine Martyrs,the monastery of St. Macarius, Wadi El-Natrun (magdy-f. 2009)

By looking to four illustrated towers, the obvious similarity can be observed between them and the described squared towers ofSyria that were constructed approximately during the 5th and 6th centuries. Although, most of the refences did not specify their construction dates, but we can deduce that they may date back to the same period. Not only because of that resemblance, but also, few references mentioned them as a part of the original building but undergonerestorations, not renovation orreconstruction, over different times. Which means that they didn't change their forms or location or even add them to the construction, they had just restored them

\subsection{Towers in Coptic Churches in the Middle of the Medieval Period (Between $7^{\text {th }}$ and $9^{\text {th }}$ centuries C.E.)}

This part of the study is the hardest one, due to the conflicts or lack of information in references, which cannot give a clear figure about what is going on Coptic belltowers that time. Unless, the old bell tower of the church of the Holy Virgin, Harat Zwayla (Figure 13). Its construction dates back to theninth century (Gawdat Gabra, Gertrud, Brooks, Ludwig, C., \& Sharif Sunbul.,2007), although others refer it to sometime before that. However, it form proves the simplicity of the pervious ancient towers, and also gives a signal of the Islamicinfluences, which was prevalent at that time where the Fatimid period, like the pointed openings at the lower level and the very tinyoctagonal shape above the squared shape. 


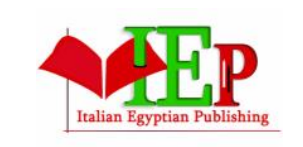

\section{INTERNATIONAL JOURNAL OF \\ MULTIDISCIPLINARY STUDIES IN ARCHITECTURE \\ AND CULTURAL HERITAGE}

shape.

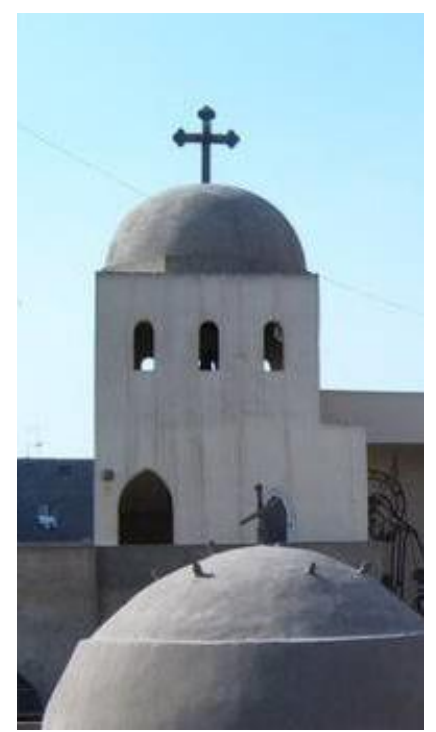

Figure 13 the old bell tower of the church of the Holy Virgin, Harat Zwayla. (restored 19th centur )(Isaac, M., 2014)

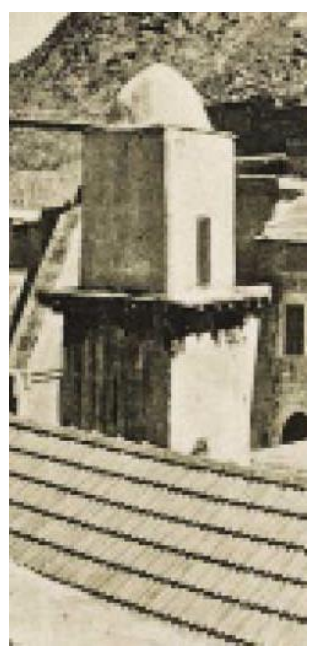

Figure 14 the minaret of the Fatimid mosque that were built in the monastery of St. Catherine, Sinai.(ShareThis Homepage, 2019).

On the other hand, the minaret of the Fatmid mosque that were built in the monastery of St. Catherine, Sinai (Figure 14), although it is not a Christian religious construction, but it is almost the only Islamicmosque built inside a Coptic monastery. It also dates to the ninth century. Its form resembles the ancient Coptic towers in their simplicity, squared base and domed top. The only difference is that the dome is pointed,as a key feature found in most Islamic heritage. This minaret is just adjacent to the church's bell-tower which is reconstructedlater and rebuilt in a totally different formbut rests on its sixth century foundations. But we can assume that the original 


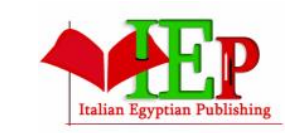

ISSN: $2735-4415$
INTERNATIONAL JOURNAL OF

MULTIDISCIPLINARY STUDIES IN ARCHITECTURE

AND CULTURAL HERITAGE

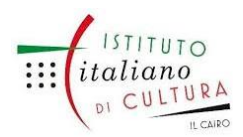

www.egyptfuture.org/ojs/

one might resemble that minaret by a way or another.

\section{6-2 Towers in Coptic Churches in the Modern Period (Between 19th and 20th centuries C.E.)}

In spite of the huge paradigm shift that took place that time due the industrial revolution, architects of churches were strongly inspired by regional influences, especially the Mediterranean. The 1923 bell- tower of the monastery of St. Pshoi (Figure 15) is slimmer than the ancient examples, has squared base, octagonal level and conical top. This form can be considered as a prototype of the renaissance churches in Europe, unless the later may miss thatoctagonal level (Figure 16).

The existing bell-tower of the monastery of St. Catherine (Figure 17). It was built by artisans who came from the Greek island of Tinos, and is constructed in a style that is prevalent on that island (St.Cathrine Monastery, 2019). Its form is very distinguished in Egypt, although it is almost typical to many churches' towers in Europe and Italy in particular (Figure 18).

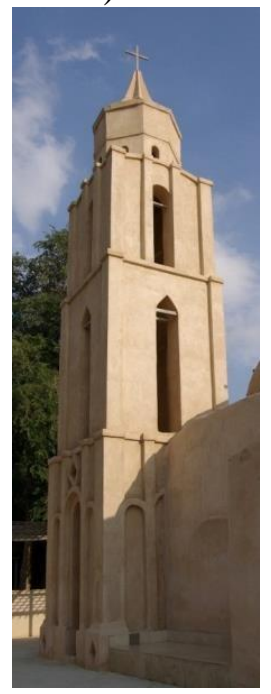

Figure 15 A bell-towers in the monastery od St.

Pshoi, Wadi El-Natrun 


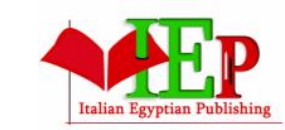

ISSN: $2735-4415$

\section{INTERNATIONAL JOURNAL OF \\ MULTIDISCIPLINARY STUDIES IN ARCHITECTURE \\ AND CULTURAL HERITAGE}

VOLUME 3, ISSUE 1, 2020, 82-98.

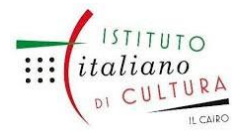

www.egyptfuture.org/ojs/

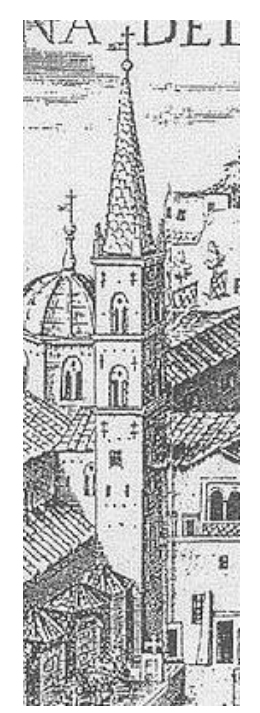

Figure 16 bell tower of the church in its originalform on Giovanni Maggi's copper engraving (1625)

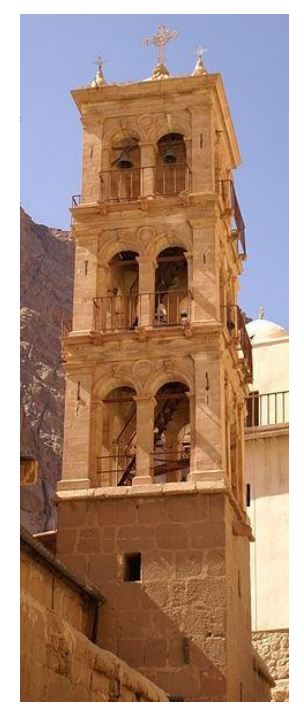

Figure 17 the present bell tower of St. Catherinemonastery, Sinai, 1871. 


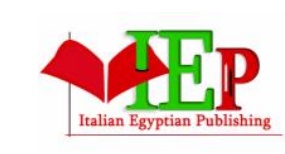

ISSN: $2735-4415$

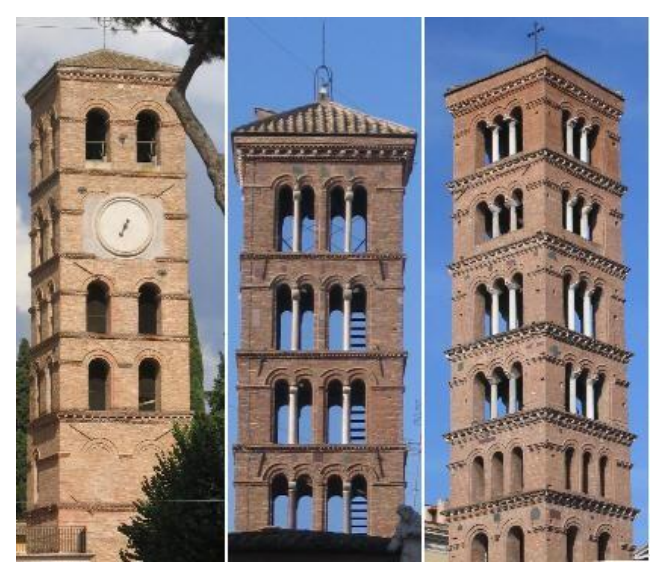

Figure 18 Bell-towers of churches: (left to right)San Lorenzo fuori le Mura; San Silvestro in Capite; $\underline{\text { Santa Maria in Cosmedin }}$

\section{5- Results and Conclusions}

According to the previous study, we can put down a number of deductions concerning the issue of the Coptic churches' bell-towers:

first of all, since Copts were from the oldest people who used bells in their churches, thanit is most portably that they were from the oldest people who erected towers for the.And although to the fragmented information about the survived or restored ones in Wadi El-Natrun and the Eastern desert, we can physically notice how much similar are they with the Squared church towers in Syria, which are for sure dates back to the fourth orfifth centuries, not after that. Which gives an obvious clue of the Coptic bell-towers that time.

Through the medieval period we cannot ignore the Islamic influence on the construction of churches generally wise, although this part of time needs more and more scrutiny. While after the industrial revolution Copts stuck to their conservative design of Churches, and that can be noticed as they were influenced with theMediterranean old structures of bell-towers.

Although it was a challenge to make astudy about the Coptic bell-towers, because of the lack of information or even the conflict between them, But it is important to go into this issue to draw or to clarify a part of the picture of the Egyptian heritage, whichwe really need to learn from and revive its knowledge. This study may consider as astart for further studies and researches about the Coptic history in general and the Coptic belltowers particularly to complete the whole image scientifically.

\section{References:}

1. Al-Maqqari, A. (2015). The Church, its building and meaning (3rd ed.). Cairo, Egypt: The ceremonial Dora of the CopticChurch.

2. Butler, A. J. (1884). The Ancient Coptic Churches of Egypt. London: Oxford, the Claredon Press.

3. Meeting Tent. (n.d.). Retrieved from St-takla.org: https://sttakla.org/pub_Bible-Interpretations/Holy-Bible-Tafsir-01-Old-Testament/Father- 
INTERNATIONAL JOURNAL OF

MULTIDISCIPLINARY STUDIES IN ARCHITECTURE

AND CULTURAL HERITAGE

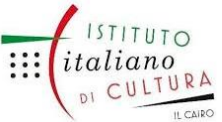

VOLUME 3, ISSUE 1, 2020, 82-98.

www.egyptfuture.org/ojs/

Antonious-Fekry/02- Sefr-El-Khoroug/Tafseer-Sefr-El-

Khroug_01-Chapter-25-b-Kheimat-Al-Egtema3.html

4. Butler, A. J. (1884). The Ancient Coptic Churches of Egypt. London: Oxford, the Claredon Press.

5. Capuani, M., Meinardus, O., Rutschowscaya, M. and Gabra, G. (2002).Christian Egypt. Cairo: American University in Cairo Press.

6. Creswell, K. (1926). The Evolution of the Minaret, with Special Reference to Egypt. The Burlington Magazine forconnoisseurs, (276), pp.134-140.

7. Dinneen, P. (1927). An Irish English Dictionary. Dublin: The EducationalCompany of Ireland.

8. Enacademic.com. (2019). [online] Available at: https://enacademic.com/pictures/enwiki/6 6/Bischoy_Kloster_BW_1.jpg [Accessed12 Oct. 2019].

9. Gawdat Gabra, Gertrud, Brooks, D. L.,Ludwig, C., \& Sharif Sunbul. (2007). The churches of Egypt: from the journey ofthe Holy Family to the present day. Cairo ; New York: The American University In Cairo Press.

10. Makar, A. (2008). The Church, its building and meaning. 2nd ed. Cairo: Nobar press, pp.159-164.

11. Mondello, A. (2017). Traditional Bell Towers: Knowledge and safety in Two Compared Areas. TEMA Technologies Engineering Materials Architecture, 3(2).

12. Quadralectic Architecture. (2019).

3.3.1.3. The square/rectangular churchplan. [online] Available at: https://quadralectics.wordpress.com/3- contemplation/3-3-churches-and-tetradicarchitecture/3-3-1-the-form-of-the- ground-plan/3-3-1-3-the- squarerectangularchurch-plan/ [Accessed14 Oct. 2019].

St.Cathrine Monastery. (2019).CATHOLICON

(BASILICA). RetrievedOctober 15, 2019, from

Sinaimonastery.com website:https://www.sinaimonastery.com/index.ph $\mathrm{p} / \mathrm{en} /$ description/the- monastery/catholicon-of-the- transfiguration

13. Stock, F. and Primer monasterio cristiano,

E. (2019). Primer Monasterio

Cristiano,Egipto (IV Siglo).

Imagen de archivo -Imagen

de primero, viejo: 24885581.

[online] Dreamstime.

Available at:

https://es.dreamstime.com/imag

en-de- archivo-primer-

monasterio-cristiano- egipto-iv-

siglo-image 24885581

[Accessed 12 Oct. 2019]. 
INTERNATIONAL JOURNAL OF

MULTIDISCIPLINARY STUDIES IN ARCHITECTURE

AND CULTURAL HERITAGE

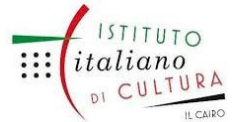

14. St-takla.org. (2019). Coptic OrthodoxMonasteries: Murals in the Church of theSyriac Monastery of the

Virgin in WadiNatrun, Egypt.

[online] Available at:https://st-

takla.org/Coptic-

History/places/monasteries/afr

ica/egypt/st

-mary-sourian/monuments-

frescoes.html[Accessed 12

Oct. 2019].

15. Westminsterabbey.ca. (2019).

The Rulesof Pachomius. [online] Available at:

http://westminsterabbey.ca/wpcontent/uploads/2018/07/Pach

omius- Rule-english.pdf [Accessed $14 \quad$ Oct.2019].

16. Wikiwand. (2019). Monastery

of SaintAnthony| Wikiwand.

[online] Availableat:

https://www.wikiwand.com/en/

Monastery

_of_Saint_Anthony [Accessed

14 Oct.2019].

17. Yousef, S. (2006). The Effects of

Religious Implications on

Churches Design in Egypt. M.Sc.

Faculty of fine Arts, Helwan

University.

19. magdy-f. (2009, February 21). مقار أبو دير

بالصود. Retrieved October 15, 2019, from

st-marina.mam9.com website: http://st-marina.mam9.com/t1179-topic

21. ShareThis Homepage. (2019). Retrieved

October 15, 2019, from ShareThiswebsite:

http://www.arabicmagazine.co

$\underline{\mathrm{m} / \mathrm{arabic} / \mathrm{ar}}$

ticleDetails.aspx ?Id=5191 
INTERNATIONAL JOURNAL OF MULTIDISCIPLINARY STUDIES IN ARCHITECTURE AND CULTURAL HERITAGE

ISSN: 2735-4415
VOLUME 3, ISSUE 1, 2020, 82-98.

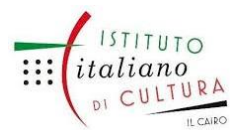

www.egyptfuture.org/ojs/

Received: February 15, 2018

Accepted: April 20, 2018 